AMERICAN JOURNAL OF SCIENTIFIC AND INDUSTRIAL RESEARCH

(C) 2011, Science Huß, http://www.scihub.org/AJSIR

ISSN: 2153-649X, doi:10.5251/ajsir.2011.2.2.136.143

\title{
Comparative studies of sun and solar drying of peeled and unpeeled ginger
}

\author{
Eze J.I and Agbo K.E \\ National Centre for Energy Research and Development, University of Nigeria, Nsukka. \\ Tel. +2348063285864, E-Mail: ikejon85@yahoo.com
}

\begin{abstract}
Fresh ginger rhizomes were washed, sorted and cut into desired sizes using a knife. Some were peeled to remove the cork skin while others were left unpeeled with the cork skin. The samples were dried in a solar dryer and the open air for two weeks and designated; solar peeled and unpeeled, and open-air peeled and unpeeled Some physico-chemical and organoleptic analyses were carried out on the samples before, during and after drying. The results obtained showed that open-air dried products retained its colour and aroma more than the solar dried samples. Drying was faster with the solar dryer than with the open air method. While the Total variable count (TVC) on the dried ginger was reduced to $66.7 \%$ for peeled and $57.6 \%$ for unpeeled ginger in the samples subjected to open-air drying, it was reduced to only $47.6 \%$ for peeled and $9.63 \%$ for unpeeled with solar drying method. The moisture content of the solar dried unpeeled ginger was reduced to $7.0 \%$ which is within the standard of $6-9 \%$ acceptable to the international market unlike that of open air drying which could only attain about $17.0 \%$ moisture content in the study area. Although there was no defined trend in changes of crude protein content of samples with drying time, solar dried ginger appeared to contain less protein than air-dried ones.
\end{abstract}

Keyword: Solar drying, Agricultural product, ginger, preservation

\section{INTRODUCTION}

Drying is essentially important for preservation of agricultural crops for future use. It preserves crops by removing enough moisture from it to avoid decay and spoilage. While water content of most agricultural produce is greater than $50 \%$, that of properly dried food varies from $5-25 \%$, depending on the food [Bhandary et al, 1997]. One of the main problems facing Nigerian farmers has remained lack of convenient method of preserving the agro-produce which is usually produced in larger quantities during harvest. The traditional open sun-drying widely practiced by rural farmers has inherent limitations; of high crop losses due to inadequate drying, fungi attacks, insects, birds, rodent encroachment and unpredictable weather effects [Ekechukwu,2010] such as dust, rain and wind; against which they are not protected [Ebewele and Jimoh, 1981]. The implication of this improper handling and drying is far reaching. For instance, it is reported that yearly, millions of dollar worth of gross national products are lost through spoilage [Fumen et al, 2003].

Solar technology has found applications in almost all areas of agriculture, namely: irrigation, powering agricultural equipment for agro processing industries and storage of agricultural produce. Solar dryers concentrate sun's radiation and dry at elevated temperature in a confined unit, thereby combining the advantages of traditional and industrial methods.

Ginger: Ginger originated from India from where it was introduced to Africa and carribean. It is now cultivated throughout the humid tropics [Meadows, 1998]. Ginger is an herbaceous perennial plant known as zingiber officinale, which belongs to the order scitamineae and the family zingriberaceae. It is grown for its pungently aromatic underground stem or rhizome which is an important export crop valued for its powder, oil and oleoresin, all of which have food and medicinal value [NEPC 1999]. Dry ginger contains essential oil 1-3\% oleoresin, $5-10 \%$, starch $50-55 \%$, moisture $7-12 \%$ with small quantities of protein, fiber, fats and ash.

Ginger production, processing and trade in Nigeria: Nigeria is among the major producers and exporters of ginger in the world. Although it is grown in six states of Nigeria namely Kaduna, Nasarawa, Benue, Niger and Gombe, southern Kaduna area of Kaduna state is the main producing zone with over $95 \%$ of the country's total production [Okafor, 2002]. Nigeria's production in 2005 which was put at 
110,000 metric tons (FAO, 2009), has increased to over sixty percent in the past five years[Guchemann 2010], $90 \%$ of which is dried primarily for export while $10 \%$ is locally consumed freshly.

Nigeria's ginger is highly valued for its aroma, pungency, high oil and oleroresin content [Njoku et al 1995] .The quality of fresh Ginger produced in Nigeria is the best in the world. However it has been observed that the quality of its dried ginger has been declining, due to low level of mechanization of ginger production and processing (Onu and Okafor, 2003), with attendant mould growth and loss of some important ginger qualities, as a result of which Nigerian ginger attracts the cheapest price in the world market (Ekundayo et. al., 1988). This tendency has attracted the attention of many players in the International market, with remarks that the quality of Nigerian ginger should be improved [Okafor and Okafor 2007].

Primary processing of freshly harvested ginger entails sorting, washing, soaking, splitting or peeling and drying it to a moisture content of $7-12 \%$ [Ebewele and Jimoh, 1981]. Processing of ginger in Nigeria has not been standardized consequent upon which low quality ginger which falls short of importer's specifications are produced. In Nigeria ginger splitting and open-air sun drying are the most widely accepted processing treatment and drying practices. Ginger peeling is done in small quantities, probably because it is tedious, time- consuming and most often, peeled dried ginger does not attract significant price difference over the split dry ginger [Ebewele and Jimoh, 1981]. According to Fumen et al (2003), processing of ginger in split dry form is preferred by farmers because that is the form demanded by the local ginger market. Other reasons for widely acceptability of split dried over the peeled dried form are flavor retention, fast and thorough drying and reduced loss of volatile oil components.

At present, the bulk of Nigeria's ginger is marketed internationally in split-dried form, where the importing countries further process it into industrial products mainly ginger powder, essential oils, oleoresin etc. These products are imported into Nigeria even at higher cost [Meadows, 1998], underscoring the need for industrial processing of Nigerian ginger within the country. Specifications for international markets are: Moisture content 6-9\%, Oil content 1-2\%, Impurities $0-2 \%$. Exports are mainly to Europe, America, and Saudi Arabia.

World trade in ginger was $3,34,433$ tones during the year 2005 of which Nigeria's share was 2.80 per cent trailing behind China (71.74\%), Nepal (5.55\%), India $(3.26 \%)$, and Thailand (3.16\%). Other countries include Netherlands (2.03\%), Philippiness (1.73\%), Brazil (1.02\%), Ethiopia (0.79\%), United Arab Emirates $(0.78 \%)$, and Taiwan $(0.77 \%)$. The main exporters of dried ginger were India, China and Nigeria while the latter two were the major suppliers to Europe [Vuatkerala, 2009]

\section{MATERIALS AND METHODS}

Fresh ginger rhizomes were procured from Ogige main market Nsukka, Enugu state, Nigeria. The ginger were sorted, washed and graded into sizes and kept in the drying chamber of a previously constructed flat plate passive solar dryer at the National Centre for Energy Research and Development, University of Nigeria, Nsukka.

Design of natural convection solar dryers: The solar dryer used in the study was fabricated at National Center for Energy Research and Development, University of Nigeria, Nsukka. A solar dryer consists of an enclosure with transparent cover. A flat plate solar collector consists of an absorber plate encased with a poline wood. The top of the wooden case was covered with ordinary transparent glass to allow for easy penetration of ultraviolet rays to the absorber plate. The absorber plate painted black was made of mild steel which is a very good conductor of heat. It is malleable available and relatively cheap. The product to be dried is placed in the drying chamber with elevated temperature due to direct absorption of heat consequent upon which moisture from the product evaporates and goes out by the natural circulation of air. 
Am. J. Sci. Ind. Res., 2011, 2(2): 136-143

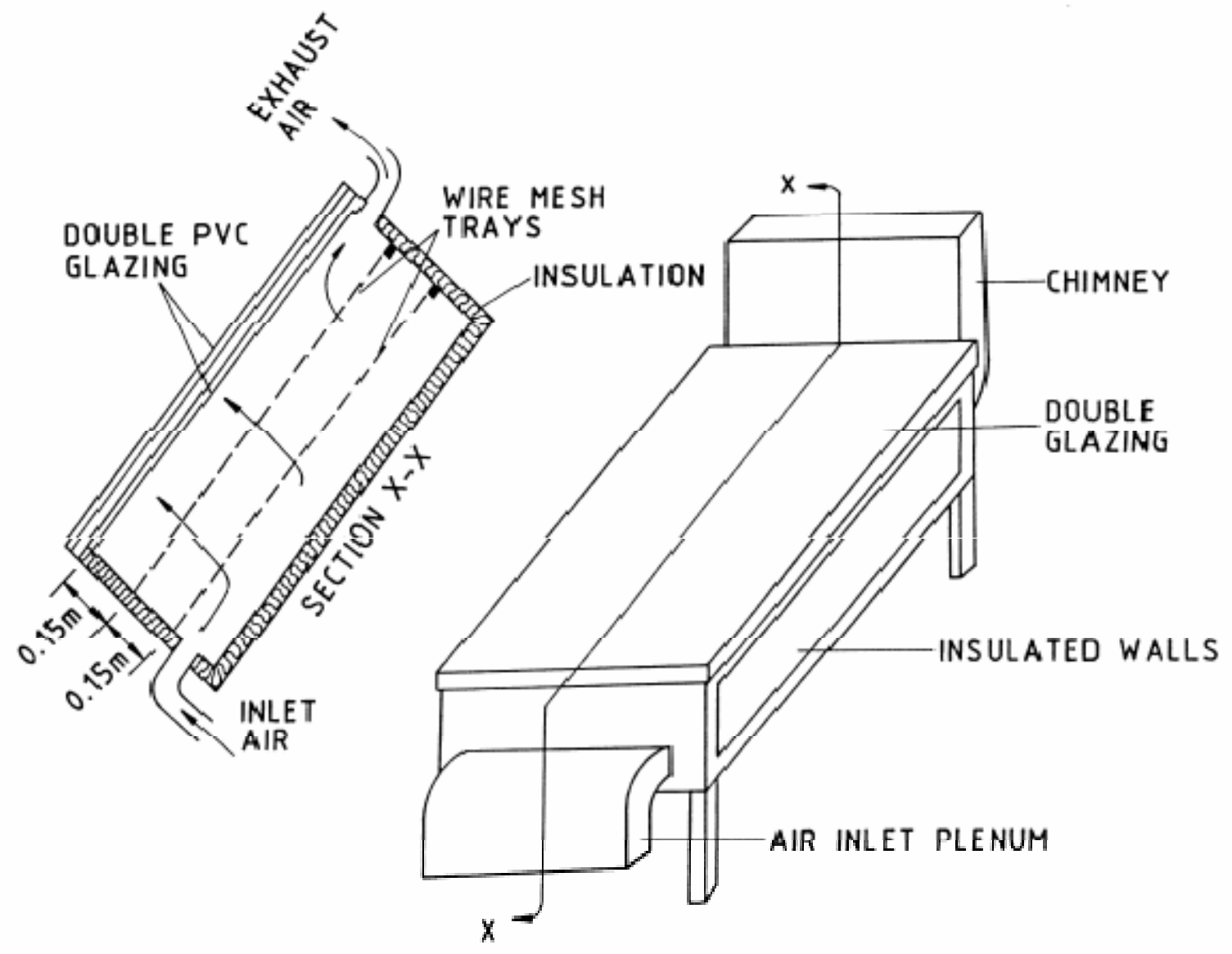

Fig 1: A modified natural-circulation solar-energy cabinet dryer.

\section{Determination of environmental conditions of the} mode of preservation: The temperature in the solar dryer and open- air were monitored daily on hourly basis using thermometer; relative humidity and solar insolation were measured using the solar energy data logger at the Energy Research Centre, University of Nigeria, Nsukka.

Determination of the Ash content: The ash content of the ginger was carried out using (Muller and Tobin, 1980) method. The crucibles (silica dishes) were heated in the oven to eliminate moisture. These were cooled in a desiccators and weighed $5 \mathrm{~g}$ of fresh sample was correctly weighed into the crucible and put into the muffle furnace .The heating started gradually till a temperature $600^{\circ} \mathrm{C}$ was reached. The furnace was then allowed to stay at this temperature for 6 hours while ash was left in the crucible for 6hours.the silica crucible was removed from the furnace after cooling and put in the desiccators and re-weighed.

$$
\% \text { Ash }=\frac{C-A}{B} \times \frac{100}{1}
$$

Where $A=$ weight of empty crucible

$$
\begin{aligned}
& \mathrm{B}=\text { weight of sample } \\
& \mathrm{C}=\text { weight of crucible }
\end{aligned}
$$

Crude fat determination: The fat content of the ginger was determined using the A.O.A.C, (1990), and the extracted percentage fat content calculated as follows:

$\%$ Fat $=\frac{\mathrm{w}_{3}-\mathrm{w}_{2}}{\mathrm{w} 1} \mathrm{x} \frac{100}{1}$

$\mathrm{W}_{1}=$ initial weight of sample, $\mathrm{W}_{2}=$ weight of beaker, $\mathrm{W}_{3}=$ weight of beaker and fat 
Crude fiber determination: The crude fiber content was determined using the method of Lewis, (1991.The samples were oven-dried to dry matter. using $50 \mathrm{ml}$ fritted glass crucibles at $100^{\circ} \mathrm{C}$ and hot weighed $\left(w_{1}\right)$. The sample was weighed into $0.1 \mathrm{mg}$ $\left(w_{2}\right)$ into $600 \mathrm{ml}$ Berzelius beaker then boiled for 5 minutes, $0.5 \mathrm{~g}$ of sodium sulphate was added using calibrated scoop $50 \mathrm{ml}$ of neutral detergent solution was also added and beaker swirled until the sample and sodium sulfite were suspended to settle for 30-60 seconds before it was filtered and washed by adding $30-40 \mathrm{ml}$ boiling water to sample in fritted glass crucible and allowed to soak for 2 minutes, the sample was then rinsed twice with $30 \mathrm{ml}$ of acetone, the crucibles were dried at $100{ }^{\circ} \mathrm{C}$ to 8 hours or overnight and was weighed $\left(w_{3}\right.$ the percentage was calculated).

$\%$ Crude Fibre $=\frac{\mathrm{w} 6-\mathrm{w} 5}{\mathrm{w} 4} \mathrm{x} \frac{100}{1}$

Where, $\mathrm{W}_{4}$ weight of crucible, $\mathrm{W}_{5}$ Initial weight of sample, $W_{6}$ Dry weight of crucible and dry fibre.

Moisture content: Moisture content was determined using the hot air oven method as described in (A.O.A.C,1990) and the percentage of moisture calculated as:

$\%$ Moisture $=\frac{\text { weight loss during drying }}{\text { original weigth of sample }} \times \frac{100}{1}$

Crude protein determination: The crude protein of the samples were determined by the Kjedahil (rack) techniques described by A.O.A.C. method (1995) and percentage of crude protein (total $\mathrm{N}_{2}$ ) was calculated as $\%$ crude

$$
=\frac{0.0001401 \times \mathrm{NR} 100 \times 6.25}{\mathrm{~W} \mathrm{N5}} \times \frac{100}{1}
$$

$T=\mathrm{m} / \mathrm{s}$ of fibre of $0.01 \mathrm{~m} \mathrm{HCl}$

W= weight of solid sample

$0.00010401=1 \mathrm{ml}$ of $0.01 \mathrm{HCl}$

Determination of total viable count (TVC): Total viable count was carried out using the method by (Frazier 1976) $1 \mathrm{~g}$ of representative sample was minced and weighed into a sterile test tube containing $9 \mathrm{ml}$ of ringer's solution, the sample was mixed thoroughly by shaking to 10 serial dilutions. Each dilution was aseptically transferred into duplicate sets of disposable sterile petri-dishes which contain nutrient agar. The petri-dishes were mixed and gentle shaken and allowed to form solid. These were incubated at $37^{\circ} \mathrm{C}$ for 24 hours after which the colonies were counted.

Sensory Evaluation: Colour and flavour of the processed ginger samples were evaluated using a 30-man sensory panelists on a 7 - point Hedonic scale.

\section{RESULTS AND DISCUSSION}

The results of proximate analysis obtained from ginger after two determinations are as shown in the Table 1.

Table 1: Changes in Daily Average Insolation Relative humidity, chamber and ambient temperature

\begin{tabular}{|l|c|c|c|c|}
\hline Time $(\mathrm{Hrs})$ & $\begin{array}{l}\text { Temperature of } \\
\text { drying chamber }\left({ }^{\circ} \mathrm{C}\right)\end{array}$ & $\begin{array}{l}\text { Ambient } \\
\text { temperature }\left({ }^{\circ} \mathrm{C}\right)\end{array}$ & $\begin{array}{c}\text { Relative humidity } \\
(\%)\end{array}$ & Average solar Insolation $\left(\mathrm{w} / \mathrm{m}^{2}\right)$ \\
\hline 800 & 28.0 & 24.8 & 83.29 & 120.39 \\
\hline 900 & 30.0 & 26.1 & 78.42 & 217.43 \\
\hline 1000 & 35.0 & 32.5 & 75.39 & 323.82 \\
\hline 1100 & 46.0 & 28.0 & 69.37 & 435.01 \\
\hline 1200 & 48.0 & 33.0 & 54.28 & 604.13 \\
\hline 1300 & 55.0 & 32.0 & 46.53 & 559.92 \\
\hline 1400 & 58.0 & 33.0 & 42.78 & 554.85 \\
\hline 1500 & 54.0 & 33.4 & 54.17 & 388.78 \\
\hline 1600 & 48.0 & 34.0 & 54.99 & 250.48 \\
\hline 1700 & 43.0 & 36.0 & 56.3 & 143.07 \\
\hline 1800 & 30.0 & 27.0 & 60.12 & \\
\hline
\end{tabular}


Table 1 shows the result of measurements of the operating conditions during the drying period of ginger samples. Temperature readings, both ambient and cabinet, showed either a definite decrease or increase. It was shown that although the two modes of storage (open- air drying and solar drying) differ, the two drying methods showed similar trends in temperature change. The temperature of the solar drying chamber was always higher throughout the drying periods. This being as a result of the fact that radiant energy incident on the transparent solar collector was trapped inside the chamber, thereby concentrating the heat inside it. While the average temperature of open-air method was $30.8^{\circ} \mathrm{C}$, the average temperature of the solar drying chamber was $43.2^{\circ} \mathrm{C}$ and rose as high as $58^{\circ} \mathrm{C}$ at 1400 hours, with corresponding relative humidity of $42.78 \%$ and solar insolation of $559.92 \mathrm{w} / \mathrm{m}^{2}$ respectively. The drying process was carried out towards the beginning of the rainy season which may be responsible for the fluctuation in the temperatures caused by unstable weather conditions. Higher temperature could have been obtained if the drying was carried out on a brighter weather.

Table 2: Drying characteristics of the peeled and unpeeled ginger under open-sun and solar drying conditions

\begin{tabular}{|c|c|c|c|c|c|c|c|}
\hline \multirow{2}{*}{$\begin{array}{l} \\
\text { Time } \\
\text { (Days) }\end{array}$} & \multirow[b]{2}{*}{ Ginger samples } & \multicolumn{2}{|c|}{ Moisture content (\%) } & \multicolumn{2}{|c|}{ Crude protein (\%) } & \multicolumn{2}{|c|}{ Total viable content (g/l) } \\
\hline & & Open Sun & Solar & Open Sun & Solar & Open Sun & Solar \\
\hline \multirow[t]{2}{*}{1} & Peeled ginger & 76.8 & 72.3 & 26.0 & 26.0 & $3.00 \times 10^{4}$ & $2.50 \times 10^{4}$ \\
\hline & Unpeeled ginger & 82.6 & 80.5 & 12.0 & 12.0 & $2.60 \times 10^{5}$ & $2.18 \times 10^{5}$ \\
\hline \multirow[t]{2}{*}{3} & Peeled ginger & 40.5 & 34.5 & 28.0 & 27.0 & $3.1 \times 10^{4}$ & $2.45 \times 10^{4}$ \\
\hline & Unpeeled ginger & 63.3 & 36.3 & 17.0 & 14.0 & $2.45 \times 10^{5}$ & $2.00 \times 10^{5}$ \\
\hline \multirow[t]{2}{*}{5} & Peeled ginger & 26.0 & 20.1 & 30.0 & 29.5 & $2.9 \times 10^{4}$ & $2.23 \times 10^{4}$ \\
\hline & Unpeeled ginger & 42.0 & 23.0 & 20.0 & 17.0 & $2.37 \times 10^{5}$ & $1.83 \times 10^{5}$ \\
\hline \multirow[t]{2}{*}{7} & Peeled ginger & 24.0 & 14.5 & 32.0 & 31.0 & $2.54 \times 10^{4}$ & $2.19 \times 10^{4}$ \\
\hline & Unpeeled ginger & 26.0 & 15.0 & 22.0 & 19.0 & $2.00 \times 10^{5}$ & $1.48 \times 10^{5}$ \\
\hline \multirow[t]{2}{*}{9} & Peeled ginger & 20.3 & 10.2 & 34.0 & 32.5 & $2.28 \times 10^{4}$ & $2.12 \times 10^{4}$ \\
\hline & Unpeeled ginger & 22.4 & 10.0 & 23.0 & 21.0 & $1.75 \times 10^{5}$ & $0.64 \times 10^{5}$ \\
\hline \multirow[t]{2}{*}{11} & Peeled ginger & 20.0 & 5.3 & 35.0 & 35.0 & $2.00 \times 10^{4}$ & $1.19 \times 10^{4}$ \\
\hline & Unpeeled ginger & 17.0 & 7.8 & 25.5 & 24.0 & $1.50 \times 10^{5}$ & $0.21 \times 10^{5}$ \\
\hline
\end{tabular}

The change in moisture content of different samples during drying is shown in Fig.2. It was observed generally that moisture content decreased as drying time increased. The results agree with the findings of (Desrosier and Desrosier 1977) who noted that drying decreases the moisture content of a product. Samples in the solar dryer, dried faster than those under the open-air sun. This is not unexpected due to higher temperatures recorded in the solar dryer. As shown in the results, there was a steady decrease in moisture content throughout the drying period.

There was no defined trend of changes in the protein content of the samples during the drying period even though the percentage of crude protein of the solardried ginger appeared to be lower than that of the open-air sun dried samples. It is most likely that the higher temperature in the solar dried samples denatured the protein. 
Am. J. Sci. Ind. Res., 2011, 2(2): 136-143

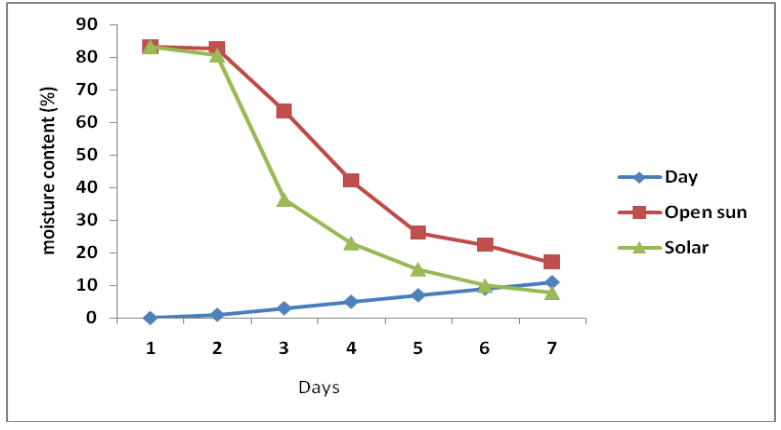

(a)

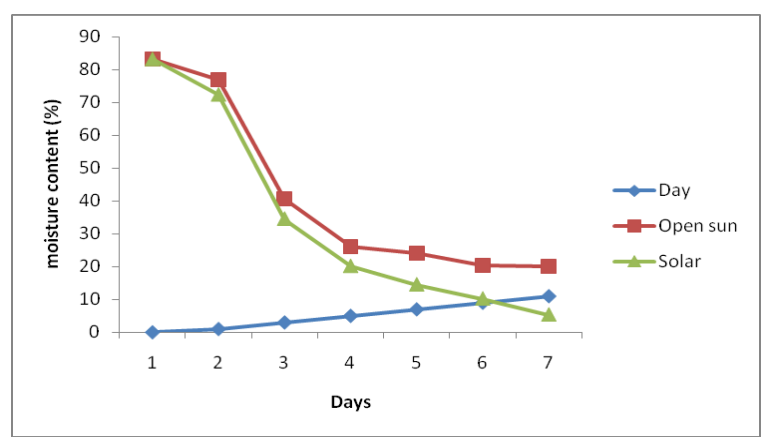

(b)

Fig 2: Changes in moisture content of Unpeeled (a) and Peeled Ginger (b) with days

While the graph of unpeeled ginger continued to fall even below $7.0 \%$ moisture content, that of peeled tended to flatten out at about $30 \%$ moisture content. This implies that the unpeeled ginger can be further dried to moisture content below $7.8 \%$. The flattening out of the graph of moisture content of the peeled Ginger may probably be due to re-absorption of moisture after drying during the night when the temperatures has fallen and the humidity level raised.

Total viable count: Figures 3 (a \& b) show the changes in microbial count of the samples during

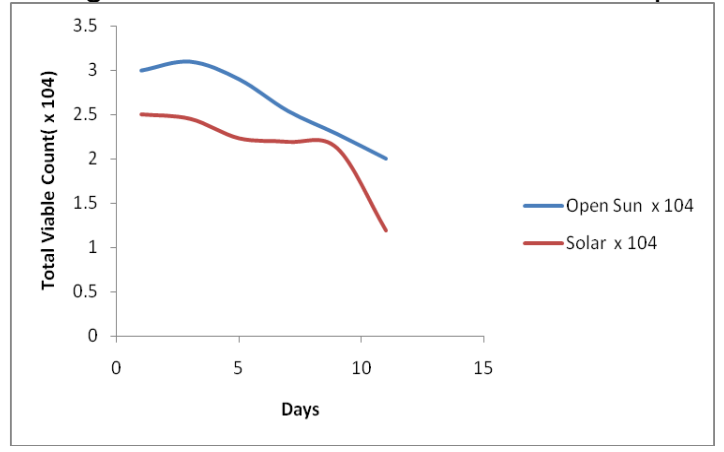

(a) drying. The microbial load decreased throughout the preservation period. The microbial load of samples fried under the sun was expectedly higher apparently because of exposure to attacks by rodents, micro organisms and contaminations from different sources. The unpeeled ginger showed a highly reduced level of microbial load as depicted in figure 3b. This may be attributed to the cork skin in the back of the unpeeled ginger which makes re-absorption of moisture extremely difficult and defends the inner part of it against microbial invasion.

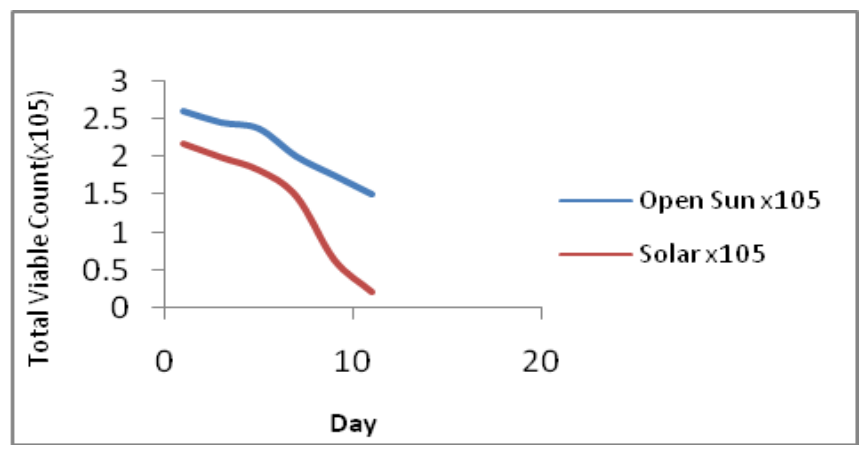

(b)

Fig 3: Changes in Total Viable Count in peeled (a) and Unpeeled (b) Ginger for Solar and Open air Drying. 
Am. J. Sci. Ind. Res., 2011, 2(2): 136-143

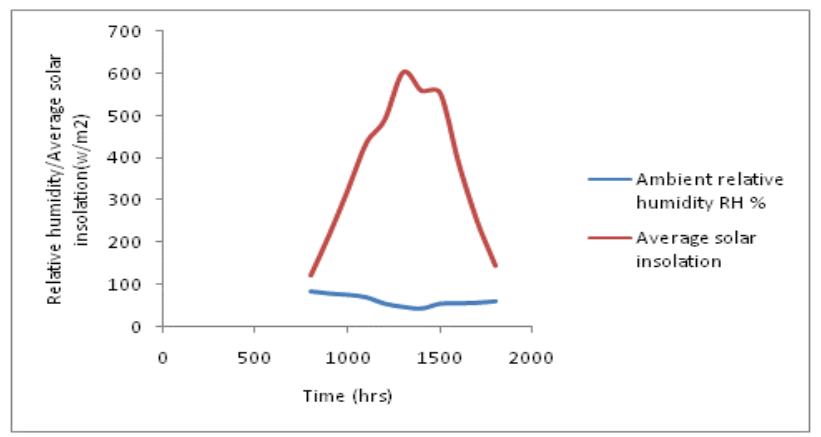

Fig 4: Changes in average Solar insolation and ambient relative Humidity with time.

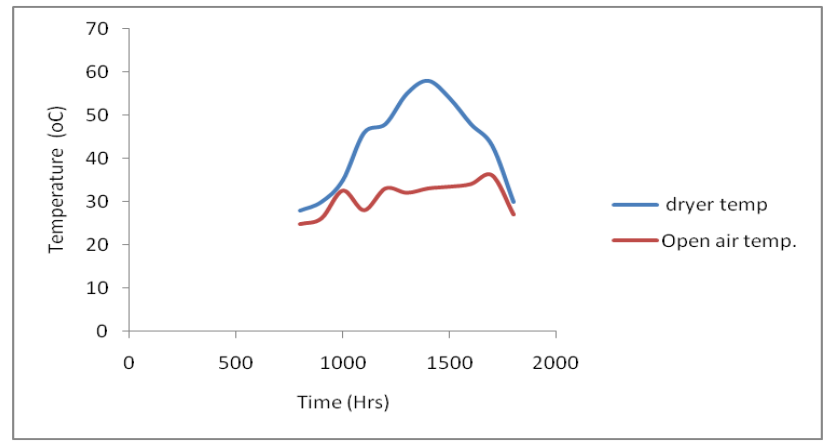

Fig 5: Changes in drying chamber temp. and ambient temp. with time

\section{CONCLUSION}

Results obtained from this research show that ginger is best preserved in its natural form under open-air sun drying conditions. Drying ginger at a higher temperature appears to denature its protein and alters its organoleptic attributes through loss of its aroma and colour; though microbiologically, use of solar dryer appears to be a better option for a safer preserved ginger product. It is therefore, being recommended that for the purpose of ginger preservation using a solar dryer, a solar dryer with a maximum of inner chamber drying temperature of not more than $40^{\circ} \mathrm{C}$ should be designed. From the results obtained this temperature will not denature the protein neither will it compromise against the microbiological qualities of ginger.

\section{REFERENCES}

AOAC, 1990. Official Methods of Analysis, 15th Edn. Association of Official Analytical Chemists, Washington D. C.

Bhandary U; Sharma J.N and Zafar R (1997). Effect of protection action of Ethanolic Ginger (zingiber officinales extract in cholestered fed rabbits. J. Ethnopharm, 61(2). 167-175.

Desrosier N.W and Desrosier J.N (1977). The Technology of Food Preservation. 4th ed, CBS Publishers, Shahdara, Delhi.

Ebewele, R.O and Jimoh A.A. (1981). Feasibility study of Kaduna state Ginger processing industry. Ahmadu Bello University chemical engineering consultant,145,50-56,63-80.

Ekechukwu V.O (2010) Solar Drying Technology: An Overview Paper presented at FUTO Alternative Energy Conference, Federal University of Technology Owerri. $16^{\text {th }} 20$ May 2010.

Ekundayo, O., Laakso, I. and Hiltunen, R. (1988). Composition of Ginger (Zingiber officinale Roscoe) Volatile Oils from Nigeria. Flavour and Fragrance J., 3:85-90.

FAO (2009) Export product Profile: Ginger. Retrieved from http;//exportNigeriablogspot .com/2009/12/export-product-profile-ginger.html

Frazier W. C. (1976), Food Microbiology, McGraw-Hill Publishing Ltd, USA, p. 71-100, 1976

Fumen G.A, Yiljee Y.D and Ajisegiri E.S.A (2003). Survey of ginger processing and drying method in Nigeria: a 
case of Southern Kaduna of Kaduna state: In proceeding of fourth institution of agricultural engineers, Damaturu, Nigeria, September $8^{\text {th }}-12^{\text {th }}$

Gucheman (2010) Focusing on Export of Ginger (Zingiber Gfficionale) produce from Nigeria. Retrievd from http://www.gucheman.com/:

Meadows A.B. (1988).Ginger processing for food and industry: In proceedings of first National Ginger workshop, Umudike, Nigeria, 34-42.

Muller HG and Tobin G (1980). Nutrition and food processing. The AVT production Co Inc. West part Connecticut. Pp 27.

Nigerian Export Promotion Council, NEPC (1999). Product profile of Ginger. Nigerian export promotion council b/k 312, Kumba st. Wuse, Zone, 11, Abuja, 1-6.

Njoku B.O, Mbanaso E.N.A and Asumugha G.N (1995) Ginger production by conventional and tissue culture techniques. Dolf madi publishers, Owerri. 13-14
Okafor G.I. (2002). Processing and Utilization of Ginger: Effect of processing methods on product quality, and its application in fruit and bakery products. TWASCSRI postdoctoral fellowship research report, CFTRI, India.p.32.

Okafor G.I. and Okafor J.N.C (2007) Effects of Pricking, Sun-drying and sieving on Ginger(Zingiber Officinale Roscoe) Colour and Powder. Nigerian Food Journal, Vol. 25, No. 1, 2007 (www.ajol.info/journals/nifoj) ISSN 0189-7241

Onu, L.I. and Okafor G. I. (2003). Effect ofphysical and chemical factor variations on the efficiency of mechanical slicing of Nigerian ginger (Zingiber officinale rose). J. Food Engineering 56:43-47.

Vuatkerala (2009)Trade Pattern (Ginger) http://www.vuatkerala.org/static/eng/trade/agri/ginger /Export\%20pattern.html 